\title{
Oxford Centre for Animal Ethics Summer School Chronology - July 2018
}

\author{
Oliver Wookey
}

LLB English and Spanish Law

MA Animal Law and Society (UAB)

Recommended citation. WOOKEY O., Oxford Centre for Animal Ethics Summer School Chronology - July 2018, dA. Derecho Animal (Forum of Animal Law Studies) 9/4 (2018) https://doi.org/10.5565/rev/da.381

\begin{abstract}
Professor Marita Giménez-Candela and myself, on behalf of the ICALP and Master of Animal Law and Society, had the pleasure of attending the Fifth Annual Oxford Summer School on Animal Ethics. This chronology details certain elements of this Conference, highlighting the key aspects and, to demonstrate the types of ideas brought and shared, describes specifically the presentations of former members of the Master in Animal Law and Society at the UAB. This piece also presents my views on the successes of the Conference on both a personal and professional level.
\end{abstract}

Keywords: Animals, Ethics, advocacy, academia, law, sentience, vegan, cruelty-free.

Resumen - Cronología de la Escuela de Verano del Centro de Ética Animal de OxfordJulio 2018

La profesora Marita Giménez-Candela y yo, en nombre del ICALP y del Máster en Derecho Animal y Sociedad, tuvimos el placer de asistir a la Quinta Escuela Anual de Verano de Oxford sobre Ética Animal. Esta cronología detalla ciertos elementos de esta Conferencia, destacando los aspectos clave y, para demostrar los tipos de ideas presentadas y compartidas, describe específicamente las presentaciones de antiguos miembros del Máster en Derecho y Sociedad Animal en la UAB. Asimismo, también expone mis puntos de vista sobre los éxitos de la Conferencia tanto a nivel personal como profesional.

Palabras clave: Animales, ética, defensa, academia, Derecho, sentiencia, vegano, sin crueldad. 
Professor Marita Giménez-Candela and myself, on behalf of the ICALP and Master of Animal Law and Society, had the pleasure of attending the Fifth Annual Oxford Summer School on Animal Ethics. The conference took place in July of this year at the University of Oxford and focused on Animal Ethics and Law, and, more specifically, 'Creating Positive Change for Animals'. This special occasion was a huge success, bringing together animal advocates from across the globe to share ideas, projects, news and updates on animal ethics. The event consisted of outstanding lectures provided by attendees, including by Professor Giménez-Candela, on behalf of the ICALP, two former students and one former teacher of the Master in Animal Law and Society. The event was as inspirational as it was instrumental in promoting a better world for animals, from dealing with topics crucial to animal welfare, to its fully vegan catering, to the dedication and enthusiasm showed and shared by everyone involved.

The conference opened on Sunday evening with a reception, a welcoming by organisers and hosts Professor Andrew Linzey and Clair Linzey, and a showing of Steven Wise's (President of the Nonhuman Rights Project) groundbreaking documentary 'Unlocking the Cage'. Monday, Tuesday and Wednesday were packed with back-to-back lectures from attendees, two at a time, varying in style and substance, from many talents of the world of animal advocacy, with lunchtimes and evenings in the beautiful St. Stephens House grounds and gardens that made for a stimulating environment for conversation and socialising. The event climaxed with the Gala Dinner on the Tuesday night, marking the successful sharing of ideas, creativity, and the boosting of motivation for another year of development for animal ethics across all relevant disciplines and areas of influence.

Throughout its duration the Conference displayed the excellent talent and potential from all corners of the of animal advocacy world, from pioneers of the movement to young upcoming minds, all of who enjoyed an academic platform to share their creativity and interest for animal ethics with other like and open-minded individuals. Attendees came from many ethics-related backgrounds, from institutes of education, animal activism organisations and agencies, the veterinary sciences, and more, all recognising the value in expertise from another field and the critical value of developing interdisciplinary understanding across the animal and ethical spectrum.

The diversity of interests among those attending made for some extremely interesting topics. A personal favourite of mine was a discussion introduced and opened up to debate by US Lawyer Andrew Bashi, questioning the effectiveness of incarceration as a means for cruelty prevention, based on striking levels of post-incarceration recidivism rates; I found this idea a fascinating issue to explore, for it uses critical thought to strive for improvements for both animals and humans, and confronts our tradition of physical confinement, with with I personally find many issues. Another brilliant topic that resonated with everyone regardless of background and experience was an investigative project carried out by Doctoral candidate at Northumbria University Rebecca Stanton, examining the cruelty that takes place under the American Humane Society's 'no animals were harmed' label used by the film industry. Her presentation shockingly exposed to the audience the various examples of inhumane treatment perpetrated upon animal actors used by the film industry in major Hollywood blockbusters that still manage to achieve the human treatment seal of approval, concluding that the laws surrounding animal actors are not stringent enough, and that this famous disclaimer serves more to protect the interests of film companies, rather than the animals they exploit.

The topic of Animal Sentience in the context of the on-going reform of the Spanish Civil Code was jointly presented by Professor Marita Giménez-Candela, Director of ICALP and Founder and Coordinator of the Master in Animal Law and Society, and Nuria Menéndez de Llano, Head of the Observatorio de Justicia y Defensa Animal, Doctoral candidate at the University of Oviedo, and Associate Fellow at the Oxford Centre for Animal Ethics. For the first half of the Presentation, Professor Giménez-Candela set out the legal background to the Spanish National Parliament's processing of the paradigmatic legal reform of the Civil Code so as to transition from the recognition of animals as things, to as sentient beings. With this 
paradigm shift already having taken place and having brought about changes in the Civil Codes of other civil law countries, this presentation effectively used this academic platform to demonstrate the process of progress in a civil law jurisdiction to other animal advocates coming from legal systems that differ in historic framework, but can nevertheless be of use in demonstrating the effectiveness of a legal paradigm shift in shaping attitudes toward animals.

In the second half of the presentation, Lawyer for Animals Nuria Menéndez de Llano detailed her highly successful "Animales no son Cosas" (Animals aren't Things) campaign. Setting out the key elements to the success of the project, she highlighted four key dimensions; social, which entailed public opinion surveys and the collection of over 350,000 online signatures; legal, which involved the detailed drafting of a legal report by experts from countries with a similarly-structured Civil Code; political, which meant several meetings with key political parties and a lobbying strategy that included meeting with main parliamentary groups; and media, which entailed the publication of articles on the campaign in national newspapers and with the Twitter hashtag AnimalesNOsonCosas that very impressively became a global trending topic. Awarded the Spanish National Marketing Award in 2018 for the best social marketing campaign, it was extremely beneficial for the prize-winning campaign strategy to have been shared with an audience of animal advocates as an exemplar for diffusing information, gaining public support and bringing about an effective change for animals.

Excellent presentations were also made by two former students and one former teacher of the Master in Animal Law and Society. Martina Pluda, student of the 4th edition of the Master and currently the Head of Programmes at Four Paws, Austria, gave an excellent presentation of Animal Law in the Third Reich, providing an historical and legal analysis of Nazi laws and their influence on German and Austrian legislation. This fascinating and wellreceived exposition argued that the many parallelisms and paradoxes in Nazi attitudes towards animals were transposed into laws that, on the one hand, represented modern and progressive answers to pressing concerns and, on the other hand, acted as a legal veil for propaganda and to level an attack on other people and their cultural traditions. This analysis of the main animal welfare and protection laws enacted in Germany from 1933 to 1942, through the duality of extrapolating and contextualising information, examined their lasting influence after the end of World War Two and the fall of the Nazi Regime, and summarises that which is analysed in greater detail in her book published in a new collection by Servei de Publicacions UAB.

Maria Helena Saari, Doctoral candidate at the University of Oulu and former student of the $5^{\text {th }}$ edition of the Master presented her argument that creating a positive change for nonhuman animals requires not only welfare reforms, but a value reform. Maria effectively presented a case for the educational setting as a space in which dominant speciesist discourse can either be reproduced or refuted, and that as dominant beliefs and practices go largely unquestioned throughout years of schooling, these well-established beliefs become harder to disprove later in life. She drew the compelling conclusion that a positive change for animals would come from critical approaches to education through human education initiatives, and through the inclusion of education legislation into the discussion and practice of animal law.

Finally, former teacher of the Master Carla Campanaro, Head of Legal Office at LAV and Doctoral Candidate at the University of Rome, presented her experience of involvement in the closing and conviction of leading members of Green Hill, a beagle breeding company used for animal experimentation in Italy. Loaded with images and footage that illustrated the graveness of the issue, the passion of the activists and finally the freedom of the beagles, the presentation made for an emotional exemplar that proved the successes possible by pursuing legal means of animal activism, with strong legal implications for breeding companies in the future.

For an animal advocate and aspiring academic, the Conference was truly motivational, from the atmosphere created by the vegan, cruelty-free catering, the ranges of 
fascinating topics demonstrating the broadness of the issues, the many issues that were tackled, to the diversity of areas of specialisation, and acknowledgement of the sheer gravity of work to be done. But, what I found to be most inspirational was the incredible amount of determination I witnessed in everyone, the shared desire to push forward and make a better world for animals our reality. The greatest minds in the field combining intellect and inspiration in an institute that constitutes the pinnacle of academic excellence has given to me, as I am sure it has to many others, an enormous boost of optimism and motivation for the future that we fight for. 